\title{
SEROLOGY USING rROP2 ANTIGEN IN THE DIAGNOSTIC OF TOXOPLASMOSIS IN PREGNANT WOMEN
}

\begin{abstract}
SUMMARY
Toxoplasma gondii causes severe fetal disease during acute infection in pregnant women, thus demanding early diagnosis for effective treatment and fetus preservation. Fetal tests are inefficient and risky, and diagnosis is based on maternal IgM serology, which had weak screening ability due to increased sensitivity, with alternative IgG avidity tests. Here, we performed ELISA and avidity assays using a recombinant $T$. gondii antigen, rROP2, in samples from 160 pregnant women screened from a large public hospital who were referred due to positive IgM assays. IgG serology and avidity assays were compared using whole T. gondii extract or rROP2. ELISA IgG detection with rROP2 showed good agreement with assays performed with $T$. gondii extract, but $\mathrm{rROP} 2 \mathrm{IgG}$ avidity assays were unrelated to whole extract antigen IgG avidity, regardless of the chaotrope used. These data show that avidity maturation is specific to individual antigen prevalence and immune response during infection. ELISA rROP2 IgG assays may be an alternative serological test for the diagnosis of toxoplasmosis during pregnancy, although our data do not support their use in avidity assays.
\end{abstract}

KEYWORDS: Toxoplasmosis; Pregnancy; Serology; Recombinant proteins; Avidity.

\section{INTRODUCTION}

Toxoplasmosis, which is usually asymptomatic, affects approximately $60 \%$ of the Brazilian population, resulting in an increased risk of congenital infection in hundreds of pregnancies each year in the Metropolitan region of São Paulo, where 200,000 children are born each year (GUIMARÃES et al., 1993). Diagnosis of acute or chronic toxoplasmosis is generally performed by serological assays, followed by confirmatory parasitological tests of fetal $T$. gondii infection (CARVALHEIRO et al., 2005). Some serological tests use live agents (Sabin Feldman assay), intact parasites, as indirect immunofluorescence assays or whole extracts in enzymatic immunosorbent assays to detect the presence of specific IgM for definition of acute (less than one year) infections during screening for treatment (REMINGTON et al., 2006). The development of commercial assays and the use of ultra-sensitive techniques such as IgM capture tests increased the sensitivity of these assays, but resulted in extended periods of IgM presence after acute infections, with consequent loss of screening efficiency (SUZUKI et al., 2001). IgG avidity was introduced for temporal definition of viral infection in rubella (LEHTONEN \& MEURMAN, 1982), and was adapted to toxoplasmosis to distinguish recent and old infections (HEDMAN et al., 1989). Avidity is based on the binding strength of specific IgG to a multivalent antigen of the parasite, which is produced at low concentrations after the primary infection, but is selectively increased over time. IgG avidity is the summation of specific affinities of antibodies present in polyclonal sera against an extract or antigen (PELLOUX et al., 1998). High avidity or chaotrope-resistant antibodies are characteristic of memory immune response and chronic infection, and the prevalence of low avidity or chaotrope-sensitive antibodies could indicate acute or recent infection. Urea is the common chaotrope used (CAMARGO et al., 1991), an alternative to ammonium thiocyanate (FERREIRA \& KATZIN, 1995). Several studies have reported that the avidity of antibody IgG is a good index of the time of the infection, defining if the acute infection has occurred in the past few months despite conflicting results between tests (BARBERI et al., 2001). Recombinant antigens were frequently tested in serology for toxoplasmosis (SUZUKI et al, 2001), usually with adequate but weak screening results compared to whole extracts in ELISA (VAN GELDER et al., 1993). The association of recombinant proteins (AUBERT et al., 2000, NIGRO et al., 2003, PIETKIEWICZ et al., 2007) or chimeric constructions (BEGHETTO et al., 2006) has improved these tests, with sporadic use in IgG avidity assays (BEGHETTO et al., 2003). Most of these studies were performed on selected sera panels defined by other tests, which could interfere in efficacy determination. Here, we standardized and tested "in house" ELISA and avidity assays using a recombinant $\mathrm{rROP} 2$ protein, and compared the results to standard assays using whole parasite extract in the serology and avidity determination of a population of IgM-positive pregnant women from São Paulo, Brazil who were referred to our specific fetal infections research group.

\section{MATERIAL AND METHODS}

Population: Pregnant women were referred to the Fetal Infection group of the Hospital das Clínicas da Faculdade de Medicina da

(1) Laboratório de Protozoologia do Instituto de Medicina Tropical de São Paulo, USP, Av. Dr. Enéas C. Aguiar 470, 05403-000 São Paulo, SP, Brasil.

(2) Depto. Parasitologia do Instituto de Ciências Biomédicas, USP, São Paulo, SP, Brasil.

(3) Grupo de Infecções Fetais, Disc. Obstetrícia, Hospital das Clínicas, Faculdade de Medicina, USP, São Paulo, SP, Brasil.

(4) IIB-INTECH, UNSAM-CONICET, Prov. Buenos Aires, Argentina.

(5) Depto. Patologia, Faculdade de Medicina, USP, São Paulo, SP, Brasil.

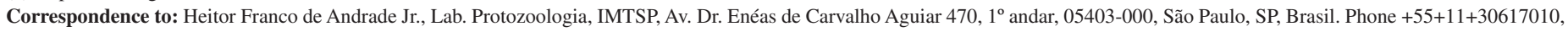
Fax $+55+11+30885237$. E-mail: hfandrad@usp.br 


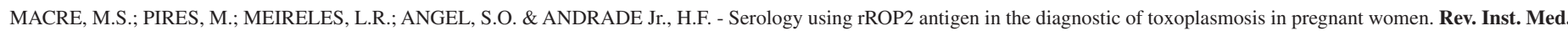
trop. S. Paulo, 51(5): 283-288, 2009.

Universidade de São Paulo (HC-FMUSP) with positive external serology for toxoplasmosis IgM by various commercially available tests for routine prenatal screening. One hundred sixty patients were enrolled in this study after informed consent. All patients were receiving regular spiramycin treatment, instituted at the time of positive $\operatorname{IgM}$ at a public health clinic, usually at least one week before entering the study. Blood was collected upon admission for confirmatory serology tests and avidity assays. Patients were then monitored clinically and analyzed by morphological ultrasound and amniotic fluid sampling when indicated, with subsequent parasitological assays or B1 PCR for introducing aggressive therapy. This program was approved and controlled by our Ethical Committee, CAPPesq under no 365/00.

Antigens: Tachyzoites of $T$. gondii RH strain were maintained routinely in the Laboratory of Protozoology of the Institute of Tropical Medicine of São Paulo. Tachyzoites were passaged in serologically negative Swiss mice (20-22g, aged 30-60 days) supplied by our central colony. The animals were injected with the tachyzoite culture intraperitoneally after washing the peritoneal cavity with sterile saline solution containing gentamycin $(40 \mu \mathrm{g} / \mathrm{mL})$. All procedures involving animals followed the rules described either in "Principles of Laboratory Animal Care" (NHI Publication in the 86-23, revised 1985) or "Principles of Ethics in Animal Experimentation" (COBEA-Brazilian School of Animal Experimentation).

Toxoplasma gondii whole saline antigen was prepared as previously described (CAMARGO et al., 1978). Briefly, tachyzoites from PBS washings of the peritoneal cavity of Swiss mice two days after infection were flowed over Sephadex G-25 columns for host cell removal and recovered by centrifugation. The sediment containing $5 \times 10^{8}$ tachyzoites was suspended in $5.0 \mathrm{~mL}$ of water and subjected to sonic rupture, five to 10 periods of 30 seconds of $40 \mathrm{~Hz}$, in an ice bath, until complete parasite disruption as assessed by phase contrast observation. The solution was added to $5 \mathrm{~mL}$ of $0.3 \mathrm{M} \mathrm{NaCl}$, which was then homogenized and centrifuged at $10,000 \mathrm{~g}$ for 30 minutes at $4{ }^{\circ} \mathrm{C}$. Protein concentration of the supernatant was calculated, and the supernatant was distributed in aliquots of $0.5 \mathrm{~mL}$, frozen at $-70^{\circ} \mathrm{C}$, and used in all experiments as whole extract.

Recombinant purified rROP2 (MARTIN et al., 1998, NIGRO et al., 2001) was produced in Escherichia coli cells by transfection with the pQE-30 vector containing a fragment of rROP2 mRNA containing 196561 base pairs and an adjacent His-Tag and stop codon. The inclusion bodies recovered after the cell membranes were disrupted and solubilized with $8 \mathrm{M}$ Urea, and the recombinant protein was affinity-purified on nickel columns. Protein content was determined and samples were distributed and stored at $-70{ }^{\circ} \mathrm{C}$ until use.

Antigen identification by SDS-PAGE and immunoblotting: The antigens were characterized by SDS-PAGE and immunoblotting with hyper-immune rabbit serum or anti-T. gondii $\mathrm{IgG}$ positive and negative human sera. Briefly, antigen was suspended in sample buffer containing $4 \mathrm{M}$ Urea and applied to $10 \%$ SDS-PAGE. After running, the proteins were transferred to a nitrocellulose membrane (TransBlot Biorad, USA) by semidry transfer, and individual strips were reacted with three antiserums: anti-T. gondii hyper-immune rabbit serum, anti- $T$. gondii IgG-positive human serum and anti-T. gondii IgG-negative human serum. After incubation, each strip was treated with adequate concentrations of specific anti-IgG peroxidase conjugates, and bands were visualized with diaminobenzidine and $\mathrm{H}_{2} \mathrm{O}_{2}$. Strips were mounted according to origin and documented.

Serological and avidity assays: Toxoplasma-specific IgG was detected using both an indirect immunofluorescence Assay (IFA) and ELISA, while IgM was detected by IFA alone. IFA was performed on slides recovered with formalin-fixed tachyzoites. Briefly, tachyzoites were obtained from mice and purified as described above, suspended in phosphate buffered saline (PBS) with $0.1 \%$ of bovine serum albumin (BSA) and fixed by the slow addition of one volume of buffered saline containing $2 \%$ formaldehyde, with constant agitation for 45 minutes at $37{ }^{\circ} \mathrm{C}$. Fixed parasites were recovered and washed with PBS by centrifugation, adjusted and distributed to multiwell immunofluorescence slides, and then drained and stored for use at $4{ }^{\circ} \mathrm{C}$. IFA was performed with a 30 minute incubation in a humidified chamber with serial dilutions of serum $(1 / 16,1 / 32,1 / 64,1 / 128,1 / 256,1 / 512,1 / 1024)$, visualized with fluorescein-conjugated anti-immunoglobulin $\operatorname{IgG}$ or $\operatorname{IgM}$, and counterstained with Evans Blue. Positive and negative controls were included in all experiments, and the slides were observed by two trained observers. A reaction was considered positive when adequate membrane fluorescence was clearly seen, although polar or nuclear fluorescence were not considered. Before performing IFA assay, all examined sera were absorbed with rheumatoid factor reagent ( $R F$-absorbens, Behring).

ELISA was performed overnight using polystyrene microwell plates coated with antigen $(10 \mu \mathrm{g} / \mathrm{mL})$ in carbonate buffer $(0.1 \mathrm{M} \mathrm{pH} 9.0)$. Free sites were blocked with $1 \%$ non-fat dry milk in PBS containing $0.02 \%$ Tween-20 (PBST). All subsequent steps were performed with four intermediate washes with PBST. Appropriate dilutions of serum samples in PBST were then applied, and bound antibody was visualized following incubation with appropriate dilutions of peroxidase-conjugated anti-human IgG (Sigma). After a 30 minute incubation with $0.05 \mathrm{M}$ sodium citrate, $\mathrm{pH} 5.8$, containing $0.4 \mathrm{mg} / \mathrm{mL}$ o-phenylenediamine (OPD), and $0.03 \% \mathrm{H}_{2} \mathrm{O}_{2}$, the reaction was stopped with the addition of $4 \mathrm{~N} \mathrm{HCl}$, and $492 \mathrm{~nm}$ absorbance is detected in a microplate reader. Avidity assays were performed similarly, with the addition of a chaotrope washing step between the serum and conjugate incubations. Chaotrope solutions were carefully adjusted to $\mathrm{pH} 7.0$ and contained $8 \mathrm{M}$ Urea and $1 \mathrm{M}$ Ammonium Thiocyanate. Avidity was expressed as percent of specific IgG that remained in the well after being washed with chaotrope compared to control wells that were maintained in PBST, subtracting the optical density of background conjugate wells. As several dilutions of sera were performed in each assay, only the dilution that gives an optical density without chaotrope between $0.5-1.5$ were used for calculation. Avidity was arbitrarily defined as low when the percent of the remaining absorbance was equal to or lower than $50 \%$, and considered to be high when the percent of the remained absorbance was higher than $70 \%$.

\section{RESULTS}

Immunoblotting clearly showed that a specific protein of approximately $40 \mathrm{KDa}$ in size was recognized by both rabbit hyperimmune anti-T. gondii antiserum and anti-T. gondii $\operatorname{IgG}$ human serum without any labeling with negative human sera, as shown in Figure 1. This data allowed us to use an ELISA for IgG using rROP2 antigen, which provided similar results to whole saline extract in the same test, as seen in Table 1. Using whole saline extract ELISA for IgG as the gold standard, the rROP2 assay was in good agreement, with $87 \%$ (95\% 
Confidence Interval or CI 60-98\%) sensitivity and a efficient specificity of $88 \%$ (95\% IC 82-93), with a high predictive positive value of $98 \%$ (95\% CI 94-100\%) despite a low negative predictive value of $43 \%(95 \%$ CI $26-62 \%$ ).

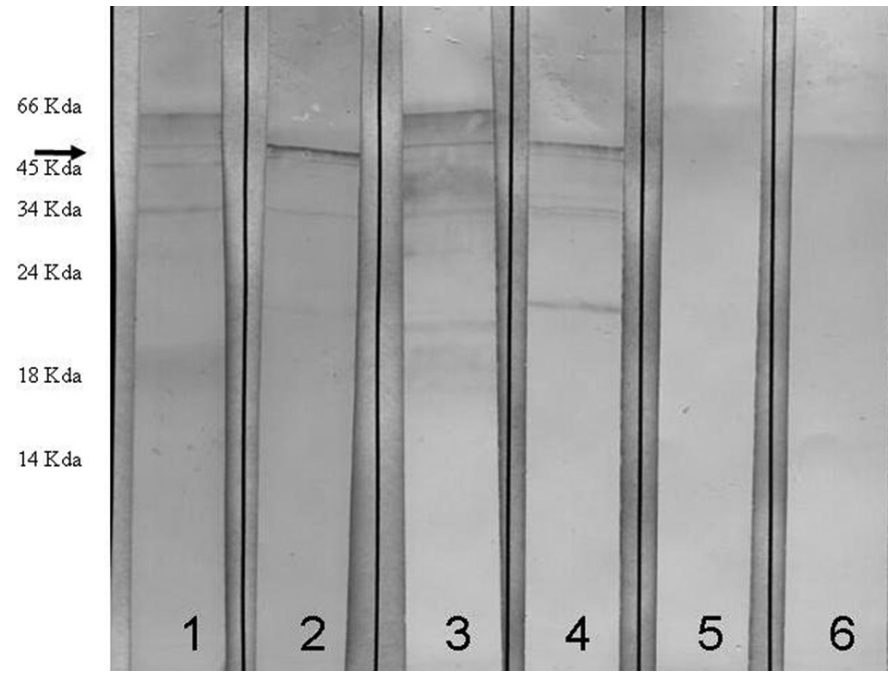

Fig. 1 - Immunochemical characterization of whole extract antigen and rROP2 antigen was revealed by SDS-PAGE with appropriate conjugates. Lanes $1,3 \& 5$ : Whole $T$. gondii extract. Lanes 2, 4 \& 6: purified rROP2. Lanes $1 \& 2$ : Antigen challenged with anti-T. gondii rabbit hyper immune serum. Lanes $3 \& 4$ : Antigen challenged with ELISA-positive human sera. Lanes 5 \& 6: Immunoblot using negative human sera. The arrow depicts rROP2 mobility.
Our sample was composed of sera from pregnant women who reported to the public health network of São Paulo and had a positive anti-Toxoplasma IgM test, which was performed during routine antinatal serological screening. We retested the women upon admission to our study, as seen in Table 1. Clearly, there are many potential pitfalls in these screening tests, resulting in large groups of screening errors. The first group consisted of seronegative women, which presented IgG ELISA-negative results in serological retests at least two weeks after screening serology. This group represented $11.3 \%$ of the sample $(18 / 160)$, having no contact with Toxoplasma gondii. The second group consisted of another type of false positive. These patients had past infections of chronic toxoplasmosis, a much more frequent condition, occurring in $66.9 \%(107 / 160)$ of the samples. After subtracting these two groups of false positives, only $21.9 \%$ (35/160) of the original sample were pregnant women recently infected with Toxoplasma gondii.

Quantitative distribution of IgG values in rROP2 ELISA can be seen in Figure 2. The distribution of $\operatorname{IgG}$ values against rROP2 was quite diverse in positive samples as compared to negative samples, although there were no differences regarding the presence of specific IgM in the sample. There is no significant relationship between quantitative data from whole extract ELISA as compared to rROP2 ELISA (Fig. 3), both in the chronically infected population (IgG+ IgM-) as well as in the recently infected population ( $\operatorname{IgG}+\operatorname{IgM}+)$, suggesting that the amount of antibodies against rROP 2 do not correlate with whole antigen antibodies.

We evaluated the avidity of IgG antibodies in these two populations using whole extract and rROP2 and two diverse chaotropes in typical

Table 1

Qualitative and quantitative comparison of ELISA assays for detection of specific IgG and its avidity using whole saline extract (WSE) or rROP2 antigen in IgMscreened samples from pregnant women reselected by confirmatory specific anti-IgM and IgG IFA assay. Avidity assays were performed only in positive samples over cut-off of $99 \%$ confidence intervals of confirmed negative samples

\begin{tabular}{|c|c|c|c|c|c|}
\hline Chaotrope & Event & $\begin{array}{c}\text { IgG and IgM } \\
\text { negative }\end{array}$ & $\begin{array}{l}\text { IgG negative and } \\
\text { IgM positive }\end{array}$ & $\begin{array}{l}\text { IgG and IgM } \\
\text { positive }\end{array}$ & $\begin{array}{l}\text { IgG positive and } \\
\text { IgM negative }\end{array}$ \\
\hline & Total N & 14 & 4 & 35 & 107 \\
\hline & ELISA IgG & 0 & 0 & 34 & 105 \\
\hline & WSE positive & & & $97.1 \%$ & $98.1 \%$ \\
\hline \multirow[t]{3}{*}{ Urea } & WSE & NA & NA & $2 / 34$ & $0 / 105$ \\
\hline & Low avidity $<50 \%$ & & & $5.9 \%$ & $0 \%$ \\
\hline & WSE mean avidity & NA & NA & $83 \% \pm 12$ & $88 \% \pm 12$ \\
\hline \multirow[t]{5}{*}{ Thiocyanate } & WSE & NA & NA & $3 / 34$ & $3 / 105$ \\
\hline & Low avidity $<50 \%$ & & & $8.8 \%$ & $2.9 \%$ \\
\hline & WSE mean avidity & NA & NA & $68 \% \pm 15$ & $72 \% \pm 16$ \\
\hline & ELISA rROP2 & 3 & 1 & 34 & 105 \\
\hline & IgG positive & $21 \%$ & $25 \%$ & $97.1 \%$ & $98.1 \%$ \\
\hline \multirow[t]{3}{*}{ Urea } & rROP2 & $0 / 3$ & $0 / 1$ & $1 / 34$ & $0 / 105$ \\
\hline & Low avidity $<50 \%$ & $0 \%$ & $0 \%$ & $2.9 \%$ & $0 \%$ \\
\hline & rROP2 mean avidity & $75 \%$ & $75 \%$ & $90 \% \pm 12$ & $90 \% \pm 15$ \\
\hline \multirow[t]{3}{*}{ Thiocyanate } & rROP2 & $0 / 3$ & $0 / 4$ & $8 / 34$ & $19 / 105$ \\
\hline & Low avidity $<50 \%$ & $0 \%$ & $0 \%$ & $23.6 \%$ & $18.1 \%$ \\
\hline & rROP2 mean avidity & $79 \%$ & $85 \%$ & $61 \% \pm 17$ & $62 \% \pm 18$ \\
\hline
\end{tabular}


MACRE, M.S.; PIRES, M.; MEIRELES, L.R.; ANGEL, S.O. \& ANDRADE Jr., H.F. - Serology using rROP2 antigen in the diagnostic of toxoplasmosis in pregnant women. Rev. Inst. Med. trop. S. Paulo, 51(5): 283-288, 2009.

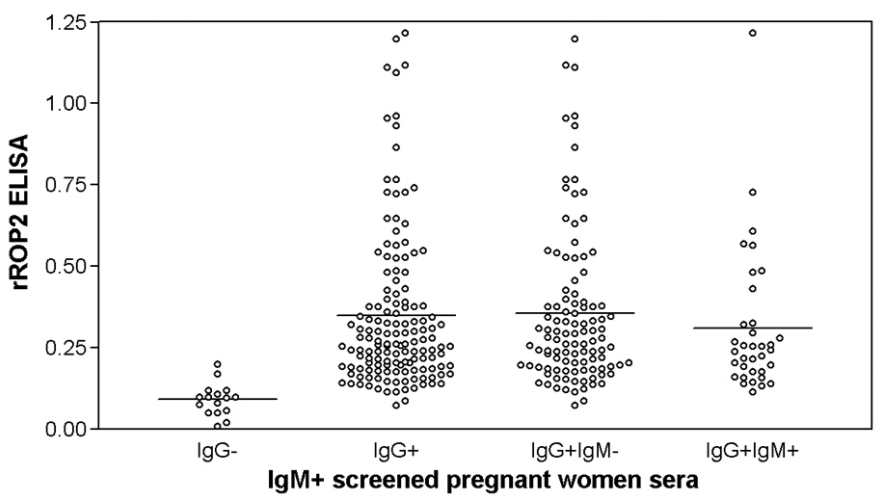

Fig. 2 - Distribution of ELISA using rROP2 antigen according to the T. gondii IgG and IgM IFA in at-risk pregnant women. Bars represent the mean value. Cutt-off values based on $99 \%$ confidence intervals of standard negative samples was 0.110 .

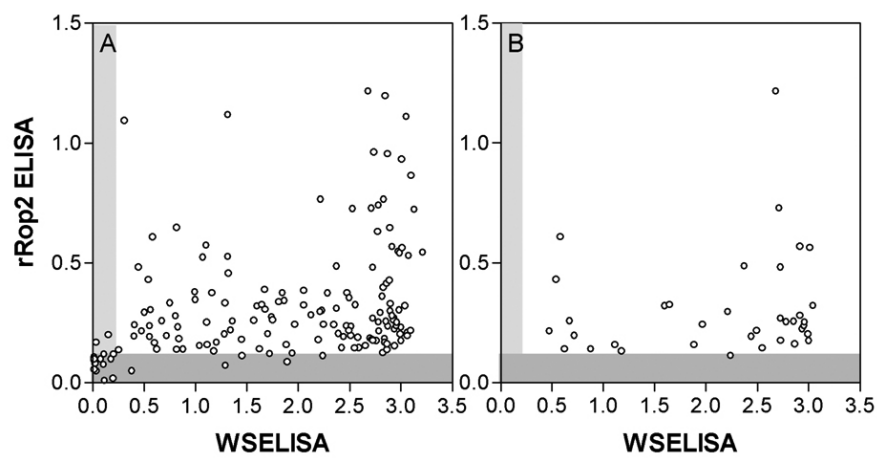

Fig. 3 - Relationship between rROP2 and whole extract quantitative ELISA for detecting anti-T. gondii $\operatorname{IgG}$ in at -risk pregnant women. A: IgG IFA-positive and B: IgG and IgM IFA-positive. Shaded areas represent negative cut off area of ELISA rROP2(0.110) and WSE(0.199).

elution ELISA avidity assays, as described in the Methods section. As seen in Figure 4 and Table 1, the mean values of $\operatorname{IgG}$ avidity were lower in the IgM+ population compared to the IgM- population for the same antigen and chaotrope. There are only a few samples with low avidity indexes, arbitrarily considered less than $50 \%$, precluding frequency comparison between assays and chaotropes. In whole extract avidity, urea was a milder chaotrope, resulting in higher avidity indexes in both antigen preparations, more clearly seen in IgM+ samples. In rROP2 avidity, this chaotrope resulted in no clear definition of recently acquired infections. In both assays, the use of ammonium thiocyanate resulted in lower avidity indexes, most clearly seen in whole extract ELISA, although those indexes were also found in chronic IgM- samples. Whole extract avidity indexes presented no relationship with rROP2 avidity indexes, which only correlated with the same test using another chaotrope, as shown in Figure 5. In fact, the relationship between avidity indexes occurred only when the same antigen was analyzed with different chaotropes.

\section{DISCUSSION}

Our patient population was composed of pregnant women screened for IgM. Most mothers presented high avidity antibodies or false positive results, which has been observed in similar studies (SPALDING et al., 2005). Following a positive test, these patients are usually grouped in the

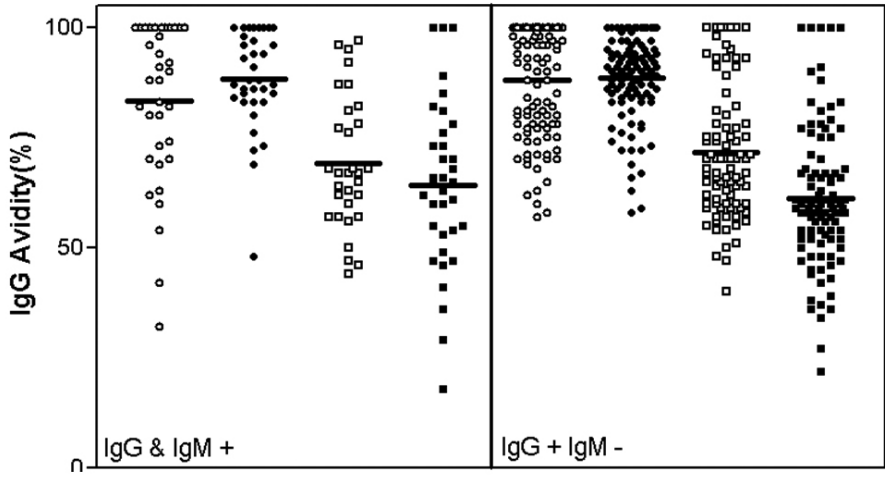

Fig. 4 - Avidity indexes in IgG-positive at-risk pregnant women selected groups using urea or thiocyanate as chaotrope and rROP2 or $T$. gondii whole extract ELISA. Open symbols represent whole extract ELISA; closed symbols represent rROP2 ELISA. Circles represent avidity indexes estimated using $8 \mathrm{M}$ Urea as chaotrope. Squares represent avidity indexes estimated using $1 \mathrm{M}$ sodium thiocyanate as chaotrope. Bars represent mean values.

Fetal infection Group in Brazil (GUIMARÃES et al., 1993), resulting in expensive spiramycin treatment of pregnant women that are not at risk of congenital infection, as well as the psychological burden to the pregnant women following the suspicion of congenital infection. This fact can be attributed to the high proportion of the adult population already infected with $T$. gondii in our area, which results in more IgM false positives compared to countries with lower rates of toxoplasmosis infection, as several reports relate false positive tests to low cut-off values (SUZUKI et al., 2001).

There was good agreement between whole extract serology and rROP2 ELISA in our sample of pregnant women screened for Tg IgM serology. There were very few negative samples, resulting in high accuracy as determined by the kappa test. The rROP2 antigen was of good quality as evaluated by immunoblot. rROP2 was further used as an antigen for the diagnosis of toxoplasmosis, although the results were disappointing (VAN GELDER et al., 1993, MARTIN et al., 1998, AUBERT et al., 2000, NIGRO et al., 2003, ALTCHEH et al., 2006, PIETKIEWICZ et al., 2007). Our data was similar to those reported by VAN GELDER et al. (1993) and those obtained with the same rROP2 source (MARTIN et al,. 1998, NIGRO et al., 2003). It is important to note that the size of the sample used in this study (160 sera) allowed us to confirm with great confidence that the version of rROP2 used was sufficient to diagnose toxoplasmosis by IgG-ELISA, especially when there are several unselected commercial tests in the screening protocol. Our study avoids any selection related to the initial IgM test used, as the study population consisted of suspected pregnant women screened at a reference center under field conditions. Several other recombinant antigens give similar results, but they were not included in the commercial assays. As the results were similar but weaker than for whole extract ELISA, attempts have been made to introduce a mixture of several recombinant antigens or chimeric proteins composed of several epitopes of diverse T. gondii proteins (BUFFOLANO et al., 2005; BEGHETTO et al., 2006; PIETKIEWICZ et al., 2007). However, all attempts have given similar results without improving upon the results of the whole extract ELISA. It is likely that the use of rROP2-ELISA could be considered on the basis of its simple and reliable development. 

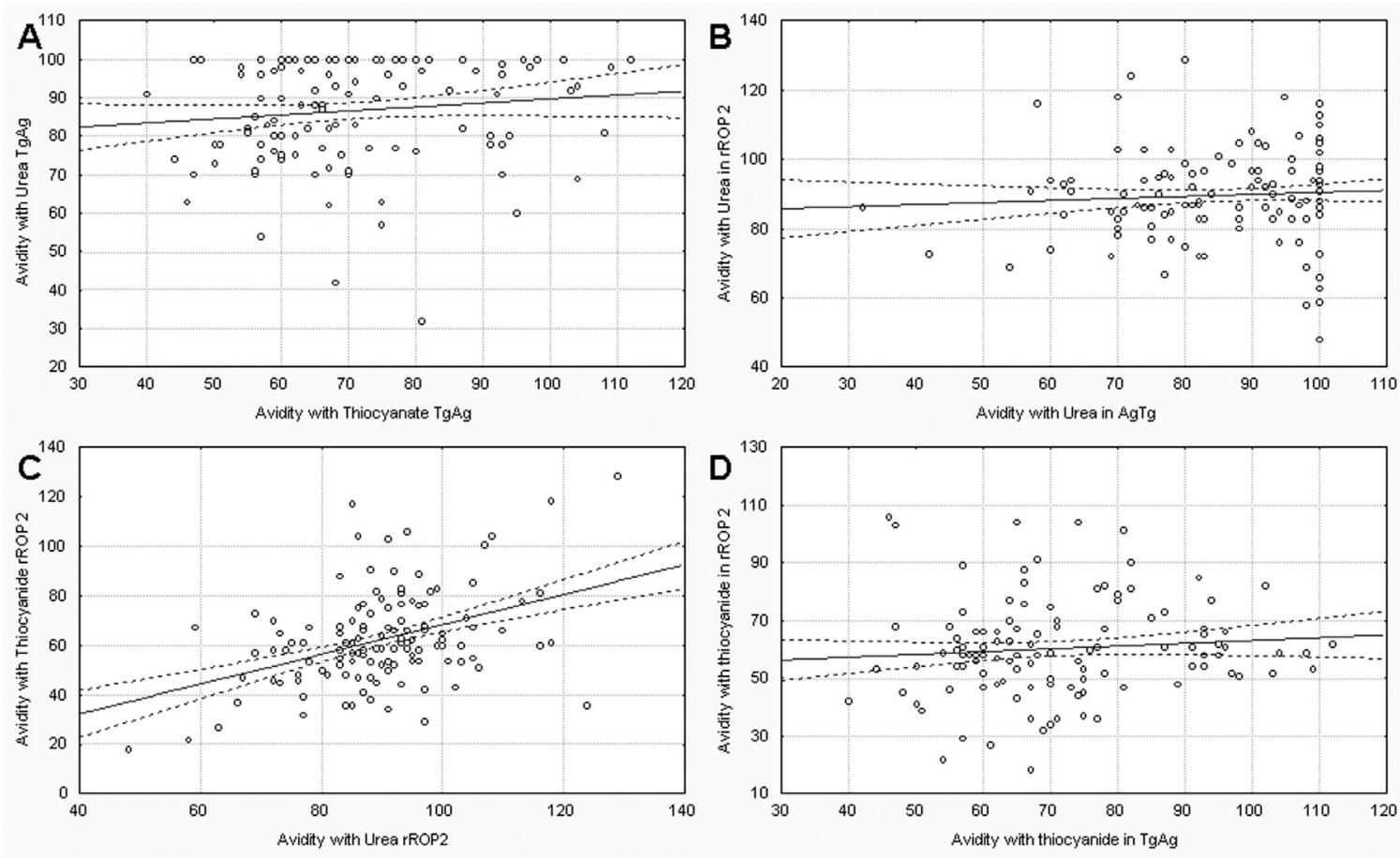

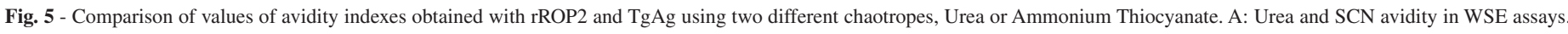
B: rROP2 and WSE avidity in urea assays. C: Urea and SCN avidity in rROP2 assays. D: rROP2 and WSE avidity in SCN assays.

Avidity data show much more complex results, as there is no relationship in quantitative analysis between assays with whole extracts or rROP2. The avidity determination was reliable for each isolated antigen regardless of the chaotrope agent, demonstrating that avidity determination is dependent on each antigen and its preparation for determination of recently acquired infections. This data could explain the conflicting results reported when comparing commercial tests available for avidity determination (BARBERI et al., 2001). Avidity is the summation of the specific antibody affinities after an infection. Thus, it is dependent on the strain of the parasite and its virulence as well as on host factors. There are several strains of $T$. gondii with variable virulence and some antigenic differences, despite the fact that all are reactive to whole extract antigens (KONG et al., 2003). These minor antigenic differences could affect ELISA with few epitopes, as observed in most isolated recombinant protein ELISA, which usually present less sensitivity and specificity than whole extract ELISA (BUFFOLANO et al., 2005). Another aspect is the parasite load in human infection, which can be acquired by oocyst ingestion of only eight sporozoites, or by tissue cysts in raw meat, containing several cysts with thousands of bradyzoites, as reported in experimental models comparing these two ways of infection and reporting that cyst induced infection was more acute and severe than oocyst induced infection (DUBEY, 2006). Thus, the immune response could be established more effectively in oocyst infection, controlling the disease before extensive infection and demanding less antibody production and selection. This is the main effect in avidity evolution, as the selection of high avidity B cell clones is dependent on antigen prevalence and the numbers of clones initially produced (TARLINGTON, 2008). Conflicting reports on avidity evolution in human toxoplasmosis has been attributed both to individual variations and to therapy (LEFEVRE-PETTAZZONI et al., 2006).
Diagnosis of recent $T$. gondii infection in pregnant women remains a difficult task despite scientific efforts to solve this problem. Screening tests continue to be based on IgM detection, although our scientific improvement on this detection method has only resulted in more false positive results and unnecessary treatments and psychological burden or, worse, unnecessary pregnancy termination in pregnant women. All efforts should be made to standardize antigen preparation in commercial tests using purified tachyzoites of standard strains, such as the RH strain, with an international consensus on assay procedures, especially for avidity assays.

The use of ELISA for specific anti-rROP2 IgG would be an alternative serological test for the diagnosis of toxoplasmosis during pregnancy, although our data do not support its use in avidity assays for recent infection detection.

\section{RESUMO}

\section{Sorologia utilizando o antígeno recombinante ROP2 no diagnóstico da toxoplasmose em mulheres grávidas}

A toxoplasmose causa grave doença fetal durante a infecção aguda da gestante, assim demanda diagnóstico precoce para tratamento efetivo e preservação fetal. Os testes fetais são de baixa eficiência e o diagnóstico é baseado na sorologia para $\operatorname{IgM}$ materna, que tem fraca capacidade de triagem devido a sensibilidade crescente dos testes, sendo uma alternativa os testes de avidez de IgG. Apresentamos aqui um ELISA e ensaio de avidez de IgG usando antígeno recombinante de T. gondii, rROP2, em amostras de 162 gestantes triadas para um grande hospital público por uma sorologia positiva para IgM. O ELISA IgG e o ensaio de avidez de 
MACRE, M.S.; PIRES, M.; MEIRELES, L.R.; ANGEL, S.O. \& ANDRADE Jr., H.F. - Serology using rROP2 antigen in the diagnostic of toxoplasmosis in pregnant women. Rev. Inst. Med. trop. S. Paulo, 51(5): 283-288, 2009.

IgG foram comparados usando o antígeno rROP2 ou extrato total de $T$. gondii. O ELISA usando rROP2 mostrou excelente concordância com os ensaios usando extrato de $T$. gondii, mas nos ensaios de avidez usando rROP2, os valores encontrados não se relacionaram com os encontrados na avidez com extrato de $T$. gondii, independente do tipo de caotrópico utilizado. Estes dados mostram que a maturação da avidez é especifica para a resposta imune ou a prevalência de um antígeno durante a infecção. Os ELISA para IgG anti rROP2 podem ser teste sorológico alternativo para o diagnóstico da toxoplasmose durante a gravidez, embora nossos dados não apóiem seu uso em ensaios de avidez de IgG.

\section{ACKNOWLEDGEMENTS}

We gratefully acknowledge the technical assistance of Roselaine P.A. Cardoso. This work was supported by LIMHCFMUSP49. M.S. Macre was a fellow of CAPES, and part of this work was used in her Master in Science dissertation. H.F. Andrade Jr. was a fellow of CNPq and FFM.

\section{REFERENCES}

1. ALTCHEH, J.; DIAZ, N.S.; PEPE, C.M. et al. - Kinetic analysis of the humoral immune response against 3 Toxoplasma gondii-recombinant proteins in infants with suspected congenital toxoplasmosis. Diagn. Microbiol. infect. Dis., 56: 161-165, 2006.

2. AUBERT, D.; MAINE, G.T.; VILLENA, I. et al. - Recombinant antigens to detect Toxoplasma gondii-specific immunoglobulin $\mathrm{G}$ and immunoglobulin $\mathrm{M}$ in human sera by enzyme immunoassay. J. clin. Microbiol., 38: 1144-1150, 2000.

3. BARBERI, A.; GISTRI, A.; CAPPELLETTI, F. \& GIORDANO, I. - Diagnostic value of IgG avidity in Toxoplasma infection: comparison of 3 commercial kits. J. infect. Dis., 184: 944-946, 2001.

4. BEGHETTO, E.; BUFFOLANO, W.; SPADONI, A. et al. - Use of an immunoglobulin $\mathrm{G}$ avidity assay based on recombinant antigens for diagnosis of primary Toxoplasma gondii infection during pregnancy. J. clin. Microbiol., 41: 5414-5418, 2003.

5. BEGHETTO, E.; SPADONI, A.; BRUNO, L.; BUFFOLANO, W. \& GARGANO, N. - Chimeric antigens of Toxoplasma gondii: toward standardization of toxoplasmosis serodiagnosis using recombinant products. J. clin. Microbiol., 44: 2133-2140, 2006.

6. BUFFOLANO, W.; BEGHETTO, E.; DEL PEZZO, M. et al. - Use of recombinant antigens for early postnatal diagnosis of congenital toxoplasmosis. J. clin. Microbiol., 43: 5916-5924, 2005.

7. CAMARGO, M.E.; DA SILVA, S.M.; LESER, P.G. \& GRANATO, C.H. - Avidez de anticorpos IgG específicos como marcadores de infecção primária recente pelo Toxoplasma gondii. Rev. Inst. Med. trop. S. Paulo, 33: 213-218, 1991.

8. CAMARGO, M.E.; FERREIRA, A.W.; MINEO, J.R.; TAKIGUTI, C.K. \& NAKAHARA, O.S. - Immunoglobulin G and immunoglobulin M enzyme-linked immunosorbent assays and defined toxoplasmosis serological patterns. Infect. Immun., 21: 55-58, 1978.

9. CARVALHEIRO, C.G.; MUSSI-PINHATA, M.M.; YAMAMOTO, A.Y.; DE SOUZA, C.B. \& MACIEL, L.M. - Incidence of congenital toxoplasmosis estimated by neonatal screening: relevance of diagnostic confirmation in asymptomatic newborn infants. Epidemiol. Infect., 133: 485-491, 2005.

10. DUBEY, J.P. - Comparative infectivity of oocysts and bradyzoites of Toxoplasma gondii for intermediate (mice) and definitive (cats) hosts. Vet. Parasit., 140: 69-75, 2006.

11. FERREIRA, M.U. \& KATZIN, A.M. - The assessment of antibody affinity distribution by thiocyanate elution: a simple dose-response approach. J. immunol. Meth., 187: 297-305, 1995.
12. GUIMARÃES, A.C.; KAWARABAYASHI, M.; BORGES, M.M.; TOLEZANO, J.E. \& ANDRADE JÚNIOR, H.F. - Regional variation in toxoplasmosis seronegativity in the São Paulo metropolitan region. Rev. Inst. Med. trop. S. Paulo, 35: 479-483, 1993.

13. HEDMAN, K.; LAPPALAINEN, M.; SEPPÄIÄ, I. \& MÄKELÄ, O. - Recent primary toxoplasma infection indicated by a low avidity of specific IgG. J. infect. Dis., 159: 736-740, 1989.

14. KONG, J.T.; GRIGG, M.E.; UYETAKE, L.; PARMLEY, S. \& BOOTHROYD, J.C. - Serotyping of Toxoplasma gondii infections in humans using synthetic peptides. J. infect. Dis., 187:1484-1495, 2003.

15. LEFEVRE-PETTAZZONI, M.; LE CAM, S.; WALlON, M. \& PEYRON, F. Delayed maturation of immunoglobulin $G$ avidity: implication for the diagnosis of toxoplasmosis in pregnant women. Europ. J. clin. Microbiol. infect. Dis., 25: 687-693, 2006.

16. LEHTONEN, O.P. \& MEURMAN, O.H. - An ELISA for the estimation of highavidity and total specific IgG and IgM antibodies to rubella virus. J. virol. Meth., 5: 1-10, 1982.

17. MARTIN, V.; ARCAVI, M.; SANTILLAN, G. et al. - Detection of human Toxoplasmaspecific immunoglobulins A, M, and $\mathrm{G}$ with a recombinant Toxoplasma gondii rop2 protein. Clin. Diagn. Lab. Immunol., 5: 627-631, 1998.

18. NIGRO, M.; GUTIERREZ, A.; HOFFER, A.M. et al. - Evaluation of Toxoplasma gondii recombinant proteins for the diagnosis of recently acquired toxoplasmosis by an immunoglobulin G analysis. Diagn. Microbiol. infect. Dis., 47: 609-613, 2003.

19. NIGRO, M.; MARTIN, V.; KAUFER, F. et al. - High level of expression of the Toxoplasma gondii-recombinant Rop2 protein in Escherichia coli as a soluble form for optimal use in diagnosis. Mol. Biotechnol., 18: 269-273, 2001.

20. PELlOUX, H.; BRUN, E.; VERNET, G. et al. - Determination of anti-Toxoplasma gondii immunoglobulin $\mathrm{G}$ avidity: adaptation to the Vidas system (bioMérieux). Diagn. Microbiol. infect. Dis., 32: 69-73, 1998.

21. PIETKIEWICZ, H.; HISZCZY SKA-SAWICKA, E.; KUR, J. et al. - Usefulness of Toxoplasma gondii recombinant antigens (GRA1, GRA7 and SAG1) in an immunoglobulin $\mathrm{G}$ avidity test for the serodiagnosis of toxoplasmosis. Parasit. Res., 100: 333-337, 2007.

22. REMington, J.S.; McLEOD, R.; THUllieZ, P. \& DESMONTS, G. Toxoplasmosis. In: REMINGTON, J.S.; KLEIN, J.O.; WILSON, C.B. \& BAKER, C.J., ed. Infectious diseases of the fetus and newborn infant. 6. ed. Philadelphia, Elsevier Saunders, 2006. p. 947-1091.

23. SPALDING, S.M.; AMENDOEIRA, M.R.; KLEIN, C.H. \& RIBEIRO. L.C. Serological screening and toxoplasmosis exposure factors among pregnant women in South of Brazil. Rev. Soc. bras. Med. trop., 38: 173-177, 2005.

24. SUZUKI, L.A.; ROCHA, R.J. \& ROSSI, C.L. - Evaluation of serological markers for the immunodiagnosis of acute acquired toxoplasmosis. J. med. Microbiol., 50: $62-70,2001$

25. TARLINTON, D.M. - Evolution in miniature: selection, survival and distribution of antigen reactive cells in the germinal centre. Immunol. Cell Biol., 86: 133-138, 2008 .

26. VAN GELDER, P.; BOSMAN, F.; DE MEUTER, F.; VAN HEUVERSWYN, H. \& HÉRION, P. - Serodiagnosis of toxoplasmosis by using a recombinant form of the 54-kilodalton rhoptry antigen expressed in Escherichia coli. J. clin. Microbiol., 31: 9-15, 1993.

Received: 25 March 2009

Accepted: 14 July 2009 